\title{
To Study the Influence of Planting Geometry and Nitrogen Level on Yield Attribute and Yield of Rice (Oryza sativa L.) under Upper Gangetic Plains Region of India
}

\author{
Shashank Shekher Singh ${ }^{1}$, Anil Kumar Singh ${ }^{1}$, Permendra Singh ${ }^{2}$, \\ A. P. Singh ${ }^{2}$ and Reena ${ }^{2}$ \\ ${ }^{1}$ Department of Agronomy, N.D. University of Agriculture and Technology, Kumarganj, \\ Ayodhya (U.P.) India-224229 \\ ${ }^{2}$ Department of Agronomy, Advanced Center for Rainfed Agriculture, Dhiansar, SKUAST- \\ Jammu (JK)-181133, India \\ *Corresponding author
}

\begin{tabular}{l} 
Ke y w o r d s \\
Planting geometry, \\
Nitrogen level, \\
Yield attribute, \\
Yield of rice \\
\hline Article Info \\
$\begin{array}{l}\text { Accepted: } \\
15 \text { February } 2020 \\
\text { Available Online: } \\
10 \text { March } 2020\end{array}$
\end{tabular}

\section{Keywords}

Planting geometry, Nitrogen level, Yield attribute , Yield of rice 10 March 2020

\section{A B S T R A C T}

A field experiment was conducted for two years during kharif season of 2017 and 2018 at Agronomy research Farm, N.D. University of Agriculture and Technology, Kumarganj, Ayodhya (U.P.) on sandy loam soil with a pH of 8.1 to study the Influence of planting geometry and nitrogen levels on rice (Oryza sativa L.)". The experiment was laid out in split plot design (SPD) with three replications Sixteen treatment combinations; comprised of four planting geometry, viz. $\left(\mathrm{S}_{1}\right) 15 \times 10 \mathrm{~cm}, 15 \times 15\left(\mathrm{~S}_{2}\right), 20 \times 10\left(\mathrm{~S}_{3}\right)$ and $20 \times 15\left(\mathrm{~S}_{4}\right)$ were kept in main plot and four nitrogen level, viz. $0 \mathrm{~kg} / \mathrm{ha}\left(\mathrm{N}_{0}\right), 60 \mathrm{~kg} / \mathrm{ha}\left(\mathrm{N}_{1}\right), 120 \mathrm{~kg} / \mathrm{ha}$ $\left(\mathrm{N}_{2}\right)$ and $180 \mathrm{~kg} / \mathrm{ha}\left(\mathrm{N}_{3}\right)$ were kept in sub plot. Under different treatments (planting geometry and nitrogen level) higher number of panicles with the value of 289.7 and 295.4 were recorded in planting geometry of $20 \times 10 \mathrm{~cm}$ which was at par with $15 \times 15 \mathrm{~cm}$ spacing while significant over rest both of the treatments while under nitrogen level higher number of panicles by 299.0 and 304.9 were recorded during 2017 and 2018 year of investigation respectively which was at par with $120 \mathrm{~kg} \mathrm{~N} /$ ha while significant over control and $60 \mathrm{~kg}$ $\mathrm{N} / \mathrm{ha}$. Whereas highest grain yield of $39.5 \mathrm{q} / \mathrm{ha}$ and $46.5 \mathrm{q} / \mathrm{ha}$ was recorded during 2017 and 2018 year respectively with planting geometry of $20 \times 10 \mathrm{~cm}$ spacing which was at par with $15 \times 15 \mathrm{~cm}$ spacing while significant over rest both of the treatments. 


\section{Introduction}

Rice (Oryza sativa L.) is the foremost staple food for more than $60 \%$ of the world's population providing major source of the food energy. It is grown in 114 countries across the world on an area about 160 million hectares with annual production of 494.3 million tonnes, and total supply of 711.5 million tonnes (Anonymous, 2015-16). Globally, total rice consumption was recorded 491.5 million metric tonnes in 2014-15 (Anonymous, 201516). It is the important crop in the country's food security accounting about $44 \%$ of the total food grain production and holds about $20 \%$ share in national agricultural GDP and provides $43 \%$ calorie requirement for more than $70 \%$ of Indians.

Plant spacing is also an important factor that needs to be considered during transplanting of rice. Rice plants compete among themselves for space, nutrients, water, sunlight, air. Proper spacing may help to increase maximum leaf Area Index (LAI), light interceptions etc. which are required for better photosynthesis as well as yield of rice.

Nitrogen plays a key role in rice production and it is required in large amount. It is one of the most important limiting nutrient in rice production and has heavy system losses when applied as inorganic sources in puddled field. Nitrogen has a positive influence on the production of effective tillers per plant, yield and yield attributes. It is necessary to find out the suitable dose of nitrogen for efficient management and better yield of rice. A suitable planting geometry and dose of nitrogen is necessary for better yield.

\section{Materials and Methods}

The field experiment was conducted during Kharif 2017 and Kharif 2018 at Agronomy Research Farm of Narendra Deva University of Agriculture and Technology, Narendra Nagar (Kumarganj), Ayodhya (U.P.). Geographically the experimental site is situated at $26^{\circ} .47^{\prime}$ North latitude and $81^{\circ} .12^{\prime}$ East longitude with is an altitude of $113 \mathrm{~m}$. from mean sea level in the Indo Gangatic Plain Zone of Eastern Uttar Pradesh. The climate in this region is sub humid. The soil is sandy loam with a $\mathrm{pH}$ of 8.1. Sixteen treatment combinations; comprised of four planting geometry, viz. $\left(\mathrm{S}_{1}\right) 15 \times 10 \mathrm{~cm}, 15 \times 15$ $\left(S_{2}\right), 20 \times 10\left(S_{3}\right)$ and $20 \times 15\left(S_{4}\right)$ were kept in main plot and four nitrogen level, viz. $0 \mathrm{~kg} / \mathrm{ha}$ $\left(\mathrm{N}_{0}\right), 60 \mathrm{~kg} / \mathrm{ha}\left(\mathrm{N}_{1}\right), 120 \mathrm{~kg} / \mathrm{ha}\left(\mathrm{N}_{2}\right)$ and 180 $\mathrm{kg} / \mathrm{ha}\left(\mathrm{N}_{3}\right)$ were kept in sub plot. The experiment was conducted in split plot design (SPD) and replicated three times.

\section{Results and Discussion}

Number of panicle $/ \mathrm{m}^{2}$, panicle length and number of grains/panicle were significantly influenced by planting geometry Table-1. Higher values of yield attributes were recorded under spacing of $20 \times 10 \mathrm{~cm}$ which was at par with $15 \times 15$ spacing. While significant over rest of the treatments yield attributing characters are the function of growth and development that develop during vegetative phase of the plant. Due to better partitioning of photosynthesis from source to sink as a result of which better growth owing to favorable growing conditions might have resulted for better development and higher value of yield attributes (Srinivasan, 1990, Verma et al., 2002 and Chopra and Chopra, 2004).

The yield attributes were primarily by the amount of nutrient. The carbohydrate production has positive correlation with levels of nitrogen. Hence, under present study increase in the value of yield attributes might be due to better translocation of carbohydrates from source to sink. 
Higher number of panicles $/ \mathrm{m}^{2}$, length of panicle, number of grains/panicle, were recorded with $180 \mathrm{~kg}$ N/hawhich was at par with $120 \mathrm{~kg} \quad \mathrm{~N} / \mathrm{ha}$ while significantly superiority over rest of the treatments. The lowest value of yield attributing characters were obtained under control and $60 \mathrm{~kg}$ nitrogen level because plants were subjected to utilize the least amount of available nitrogen which resulted into reduced translocation of photosynthates from source to sink and thus led to poor yield attributing characters. The results of present investigation in respect of these yield attributes are in agreement with the findings of Banerjee et al., 2011 and Prakash et al., 2011 who reported the response of rice crop to nitrogen in attributing the yield attributes.

Grain yields of rice influenced significantly by planting geometry of crop. The plant geometry under 20x10 cm resulted in higher grain yield which was at par with $15 \times 15 \mathrm{~cm}$ spacing while significant over rest both of the treatments and lowest grain yield under $15 \times 10$ cm planting geometry was obtained. Yield is functions of complex inter relationship of growth in vegetative phase and yield attributes, this may due to better translocation of assimilation. Rajesh and Thanuthan (2003), Powar and Deshpande (2001) and Shinde et $a l .$, (2005) also reported similar results.

The yield was recorded higher under $180 \mathrm{~kg}$ $\mathrm{N} / \mathrm{ha}$ which was at par with $120 \mathrm{~kg} \mathrm{~N} / \mathrm{ha}$ and significant as compared to other treatments. This might be due to adequate nitrogen availability which contributed to increased dry matter accumulation. Productivity of a crop is collectively determined by vigour of the vegetative growth, development as well as yield attributes which is the result of better translocation of photosynthates from source of leaves and stem to the grains. Better vegetative growth coupled with high yield attributes resulted into higher grain yield in said treatments Prakash et al., (2014) and Nayak et al., (2014) also reported similar results.

Table.1 Influence of planting geometry and nitrogen levels on yield attributes of transplanted rice

\begin{tabular}{|c|c|c|c|c|c|c|c|c|}
\hline \multirow[t]{2}{*}{ Treatments } & \multicolumn{2}{|c|}{$\begin{array}{c}\text { No. of panicles/ } \\
\text { m2 }\end{array}$} & \multicolumn{2}{|c|}{$\begin{array}{l}\text { No. of grain/ } \\
\text { panicle }\end{array}$} & \multicolumn{2}{|c|}{$\begin{array}{c}\text { Length of Panicle } \\
(\mathbf{c m})\end{array}$} & \multicolumn{2}{|c|}{ Test Weight(g) } \\
\hline & 2017 & 2018 & 2017 & 2018 & 2017 & 2018 & 2017 & 2018 \\
\hline \multicolumn{9}{|c|}{ Planting Geometry } \\
\hline $15 \mathrm{~cm} \times 10 \mathrm{~cm}$ & 238.5 & 243.2 & 149.8 & 151.4 & 23.7 & 23.9 & 22.8 & 22.8 \\
\hline $15 \mathrm{~cm} \times 15 \mathrm{~cm}$ & 283.2 & 289.8 & 164.8 & 161.4 & 25.7 & 27.2 & 23.3 & 23.3 \\
\hline $20 \mathrm{~cm} \times 10 \mathrm{~cm}$ & 289.7 & 295.4 & 197.7 & 166.4 & 26.7 & 27.5 & 23.4 & 23.4 \\
\hline $20 \mathrm{~cm} \times 15 \mathrm{~cm}$ & 278.5 & 283.4 & 159.7 & 159.4 & 25.5 & 27.0 & 23.2 & 23.2 \\
\hline SEm \pm & 6.81 & 6.95 & 4.10 & 4.02 & 0.64 & 0.64 & 0.11 & 0.13 \\
\hline $\mathrm{CD}(\overline{\mathbf{P}}=\mathbf{0 . 0 5})$ & 23.57 & 24.05 & 14.21 & 13.91 & 2.21 & 2.23 & NS & NS \\
\hline \multicolumn{9}{|c|}{ Nitrogen levels (Kg/ha) } \\
\hline $\mathbf{0}$ & 206.0 & 210.2 & 139.4 & 140.9 & 23.4 & 23.6 & 22.2 & 22.2 \\
\hline 60 & 276.0 & 291.7 & 147.2 & 148.8 & 25.9 & 25.1 & 22.9 & 22.9 \\
\hline 120 & 292.0 & 300.9 & 160.0 & 163.6 & 26.4 & 26.7 & 23.6 & 23.6 \\
\hline 180 & 299.0 & 304.9 & 163.5 & 165.1 & 26.9 & 27.2 & 23.8 & 23.9 \\
\hline SEm \pm & 5.62 & 5.73 & 2.12 & 2.23 & 0.51 & 0.52 & 0.10 & 0.12 \\
\hline $\mathrm{CD}(\overline{\mathrm{P}}=\mathbf{0 . 0 5})$ & 16.41 & 16.74 & 6.13 & 6.51 & 1.51 & 1.53 & NS & $\mathrm{NS}$ \\
\hline
\end{tabular}


Table.2 Influence of planting geometry and nitrogen levels on Grain(q/ha), Straw yield (q/ha) and Harvest index of transplanted rice

\begin{tabular}{|c|c|c|c|c|c|c|}
\hline \multirow[t]{2}{*}{ Treatments } & \multicolumn{2}{|c|}{$\begin{array}{l}\text { Grain } \\
\text { Yield(q/ha) }\end{array}$} & \multicolumn{2}{|c|}{$\begin{array}{l}\text { Straw } \\
\text { Yield(q/ha) }\end{array}$} & \multicolumn{2}{|c|}{ Harvest Index (\%) } \\
\hline & 2017 & 2018 & 2017 & 2018 & 2017 & 2018 \\
\hline \multicolumn{7}{|c|}{ Planting Geometry } \\
\hline $15 \mathrm{~cm} \times 10 \mathrm{~cm}$ & 35.4 & 36.4 & 53.6 & 57.1 & 41.2 & 39.8 \\
\hline $15 \mathrm{~cm} \times 15 \mathrm{~cm}$ & 37.3 & 45.5 & 65.6 & 68.4 & 41.7 & 41.5 \\
\hline $20 \mathrm{~cm} \times 10 \mathrm{~cm}$ & 39.5 & 46.5 & 67.0 & 69.6 & 41.9 & 41.8 \\
\hline $20 \mathrm{~cm} \times 15 \mathrm{~cm}$ & 37.0 & 39.5 & 55.2 & 66.5 & 41.7 & 41.0 \\
\hline SEm \pm & 1.2 & 1.2 & 1.7 & 1.7 & 0.1 & 0.1 \\
\hline $\mathrm{CD}(\overline{\mathbf{P}}=\mathbf{0 . 0 5})$ & 4.2 & 4.4 & 5.9 & 6.1 & 0.4 & 0.4 \\
\hline \multicolumn{7}{|c|}{ Nitrogen levels kg/ha } \\
\hline 0 & 30.9 & 32.2 & 47.4 & 49.1 & 39.4 & 39.5 \\
\hline 60 & 40.8 & 41.5 & 57.9 & 60.2 & 41.9 & 40.9 \\
\hline 120 & 44.3 & 44.7 & 62.7 & 65.7 & 42.5 & 42.6 \\
\hline 180 & 45.0 & 45.5 & 63.4 & 66.5 & 42.6 & 42.7 \\
\hline SEm \pm & 1.09 & 1.1 & 1.47 & 1.52 & 0.1 & 0.20 \\
\hline $\mathrm{CD}(\overline{\mathrm{P}}=\mathbf{0 . 0 5})$ & 3.1 & 3.3 & 4.29 & 4.4 & 0.3 & 0.58 \\
\hline
\end{tabular}

Table.3 Interaction effect of planting geometry and nitrogen levels on grain yield (q/ha)

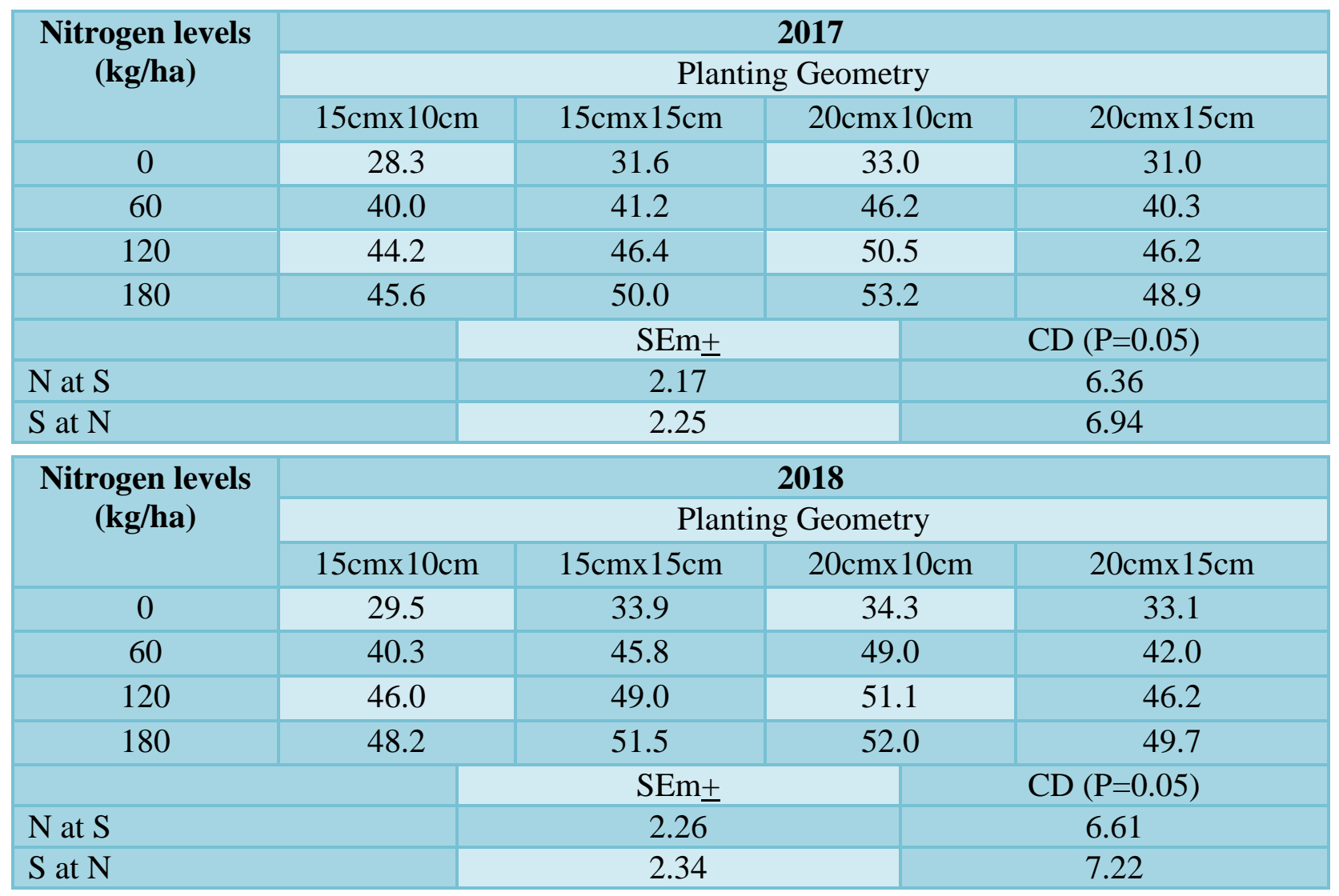


Table.3 Interaction effect of planting geometry and nitrogen levels on straw yield (q/ha)

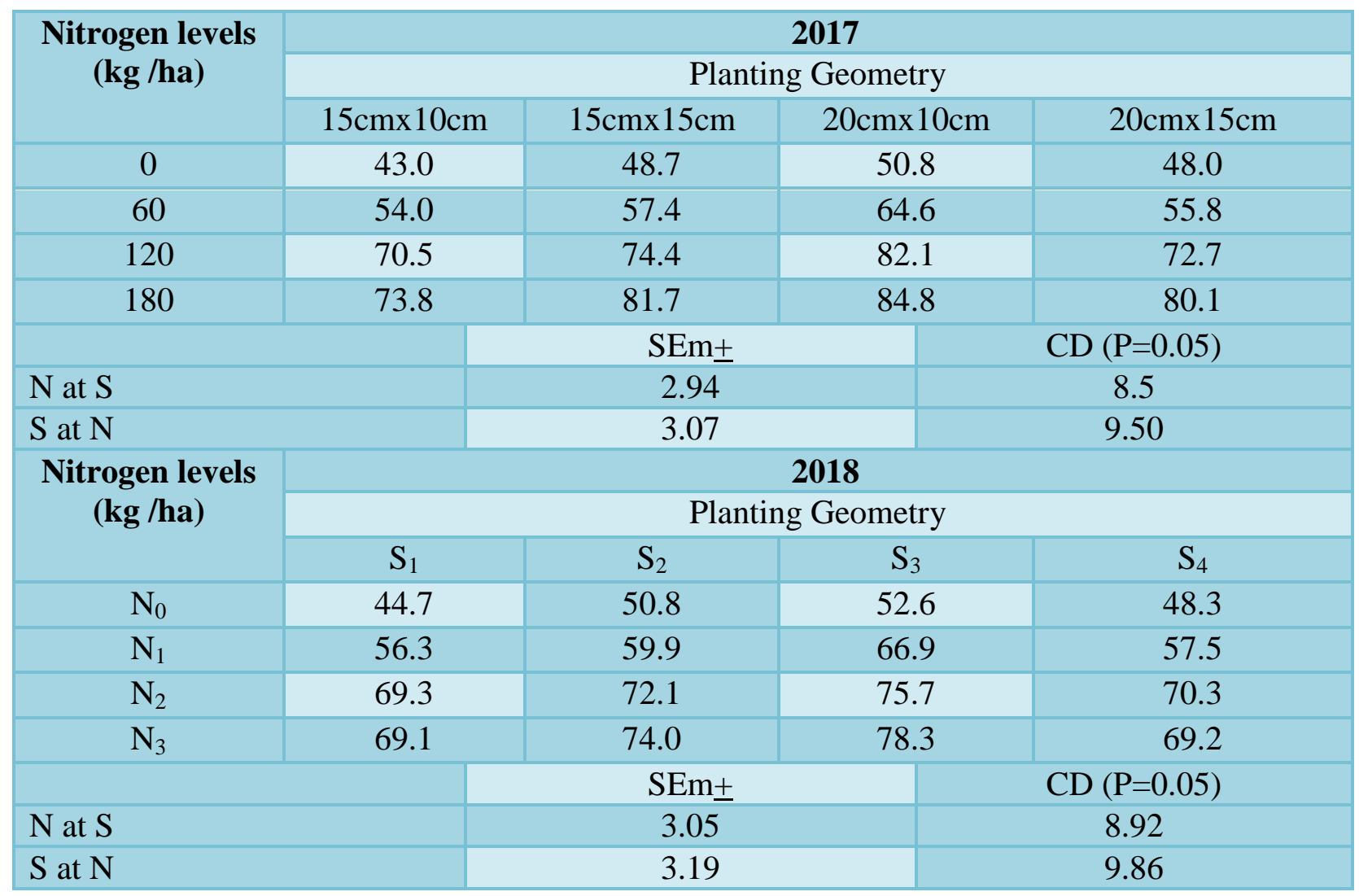

Straw yield of rice were highest when rice crop was planted by $20 \times 10 \mathrm{~cm}$ spacing which was at par with $15 \times 15 \mathrm{~cm}$ planting geometry . Higher number of tillers $/ \mathrm{m}^{2}$ with plant height and better growth. Ultimately led the increased biomass in $20 \times 10 \mathrm{~cm}$ of rice spacing. The lowest yield was recorded under $15 \times 10 \mathrm{~cm}$ spacing due to lesser number of tillers $/ \mathrm{m}^{2}$ for available growth resources on account of more competition (Shinde et al., 2005; Jalil, 2008)

Harvest index was significantly affected due to planting geometry during both the years of investigation. Higher harvest index was found significantly with $20 \times 10 \mathrm{~cm}$ planting geometry mainly due to proportionately higher grain yield relative to biomass.

Increase in $\mathrm{N}$ availability increase the harvest index of transplanted rice during both the years of investigation. Higher harvest index were recorded under $180 \mathrm{~kg} \mathrm{~N} / \mathrm{ha}$ which was at par with $120 \mathrm{~kg} \mathrm{~N} / \mathrm{ha}$ due to higher grain yield (economic yield) relative to biomass (Prakash et al., 2014).

In conclusion, the data collected were subjected to statistical analysis to draw valid conclusion. Planting geometry of $20 \mathrm{~cm} \times 10 \mathrm{~cm}$ was found suitable for higher yield attributes and yield of rice.

\section{References}

Anonymous (2015-2016). Directorate of economics and statistics, department of agriculture and corporation, Ministry of agriculture, Government of India. 19: 27-41.

Chopra, N.K. and Chopra, N. (2004). Seed yield and quality of 'Pusa44' rice as 
influenced by nitrogen fertilizer and row spacing. Indian Journal of Agricultural Sciences, 74(3): 144-146.

Srinivasan, K. (1990). Effect of plant spacing on ratoon rice performance. IRRN, 15(4): 21.

Verma, A.K., Pandey, N. and Tripathi, S. (2002). Effect of transplanting spacing and number of seedlings on productive tillers, spikelet sterility, grain yield and harvest index of hybrid rice. IRRN, 27(1): 51.

Banerjee, H. and Pal, S. (2011). Effect of planting geometry and different levels of nitrogen on hybrid rice. Oryza, 48(3): 274-275.

Nayak, A., Mohapatra, L.N., Mohanty, S.K., Mishra, G.C. and Das, L.K. (2014b). Effect of integrated nutrient management practices on yield and economics in system of rice intensification (SRI) in western undulating zone of Odisha. In: Extended Summaries, National Symposium on Management options for enhancing farm productivity and livelihood security under changing climate, 29-31 October 2014, Bhubaneswar. pp. 58-60.

Powar, S.L. and Deshpande, V.N. (2001). Effect of integrated agro-technology on Sahyadri hybrid rice in medium black sail in high rainfall area. Journal of Maharashtra Agriculture University, 26(3): 272-276.

Prakash, C., Koli, N.R., Shivran, R.K., Sharma, J.C. and Kumar, R. (2014). Response of nitrogen levels and weed management practices on productivity of rice(Oryza sativa L.) under aerobic condition. Bioinfolet 11 (1 A): 145-148.

Rajesh, V. and Thanunathan, K. (2003). Effect of seedling age, number and spacing on yield and nutrient uptake of traditional Kambanchamba rice. Madras Agriculture Journal, 90(1-3): 47-49.

Jalil, M.A. (2008). Effect of spacing and seed rate of fertilizer application on yield performance of Boro rice (cv. BRRI Dhan 29) under aerobic system of cultivation. M.Sc. Thesis, Department of Agronomy, Bangladesh Agricultural University, My memsingh. Pp. 48-49.

\section{How to cite this article:}

Shashank Shekher Singh, Anil Kumar Singh, Permendra Singh, A. P. Singh and Reena. 2020. To Study the Influence of Planting Geometry and Nitrogen Level on Yield Attribute and Yield of Rice (Oryza sativa L.) under Upper Gangetic Plains Region of India. Int.J.Curr.Microbiol.App.Sci. 9(03): 2174-2179. doi: https://doi.org/10.20546/ijcmas.2020.903.249 